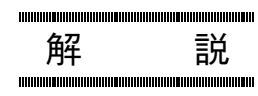

\title{
昆虫の嗅覚やその機能からセンサを再現する
}

\author{
光 野 秀 文*1, 祐 川侑 司*1, 櫻 井 健 志*2, 神 崎 亮 平*1 \\ 東京大学先端科学技術研究センター*1, 東京農業大学農学部 ${ }^{* 2}$
}

\section{Reconstruction of Odor Biosensors Based on Insect Olfaction}

Hidefumi Mitsuno, ${ }^{* 1}$ Yuji Sukekawa, ${ }^{* 1}$ Takeshi Sakurai ${ }^{* 2}$ and Ryohei Kanzaki*1

Research Center for Advanced Science and Technology (RCAST), The University of Tokyo*1 Faculty of Agriculture, Tokyo University of Agriculture*2

\section{概要}

昆虫は環境中の多種多様な化学情報 (匂い情報) を, 触角の嗅覚受容体を使って検出し, 脳 内で情報処理することで環境適応行動を示す. 拈よそ 20 年前に初めてキイロショウジョウバ 工の嗅覚受容体が発見されて以降, 現在までにさまざまな昆虫種で嗅覚受容体が同定され嗅覚 機能の解明が進み, 匂いに対する応答特性から, 応答特性の情報処理機構, 環境適応行動の発 現に至るしくみが明らかにされつつある。 また, 所望の昆虫種での遺伝子組換え, 異生物種培 養細胞での嗅覚受容体機能の再構築など, 対象遺伝子を人工的に操作する遺伝子工学技術が進 展してきた. 現在では, 昆虫の嗅覚機能の知見と遺伝子工学技術を活用して昆虫の嗅覚のしく みを部分的に再現することにより, 嗅覚受容神経の嗅覚受容体の遺伝子を組換えることで対象 の匂い物質 (対象臭) を探索し定位できる「センサ昆虫」, 対象臭を蛍光変化として検知できる 「センサ細胞」の開発が可能となってきた。ささらに，複数種類のセンサ細胞をアレイ化するこ とで，生物のように応答パターンで匂い混合物の識別や濃度を定量できる「匂いセンサ技術」 の開発も可能となってきた。このように，匂いセンシング技術の一つとして昆虫の嗅覚の有用 性が実証され，一部の技術では社会実装に向けた研究も活発に進められている状況にある。

\section{1. は じめに}

環境中には多種多様な揮発性の化学物質 (匂い物質) が漂っている。われわれをはじめとする生物は，この ような環境の中で対象の匂い物質 (対象臭)を検出する ことにより，環境情報の変化をとらえ，その環境にあっ た適応行動を示す。生物の中でも昆虫は嗅覚が優れて おり, 哺乳類とは異なるしくみで構成される嗅覚系を 進化させてきた。特に, 昆虫で機能する嗅覚受容体は 共受容体 (Olfactory receptor co-receptor : Orco) と ともにイオンチャネルとして機能する．そのため受容 体が受け取る匂い情報はイオン電流やイオン濃度変化 として計測することができる。このしくみを遺伝子工 学技術で生物や培養細胞で再現することで, 人為的に 匂い物質を検出する素子が構築できる。本稿では, 昆 虫の嗅覚のしくみを概説したのち, 昆虫の嗅覚受容体

\footnotetext{
*1 ₹ 153-8904 東京都目黒区駒場 4-6-1

*2 ₹ 243-0034 神奈川県厚木市船子 1737
}

を用いて開発してきた，匂い源定位する「センサ昆虫」， 匂いを蛍光変化としてとらえる「センサ細胞」, そして 匂いを応答パターンで識別・濃度定量する「匂いセン サ技術」について紹介する。

\section{2. 昆虫の嗅覚のしくみ}

昆虫は頭部に付属する一対の触角で主に匂いを受容 する (図 1A). 昆虫の触角には感覚子と呼ばれる主に 突起状の形態をした構造体が多数存在し, これらの感 覚子は味, 湿度, 機械感覚など多様な感覚の受容器とし て機能する。感覚子のうち嗅覚受容に関するものは嗅 感覚子と呼ばれ，クチクラ上に開いた嗅孔と呼ばれる 微小な穴 (直径数 $10 \mathrm{~nm}$ ) の存在により他の感覚子と区 別できる (図 $1 \mathrm{~B}$ ). 嗅感覚子の内部には通常複数の嗅 覚受容神経が配置されており, 匂い受容部位である樹 状突起を感覚子内部に, 軸索を昆虫の嗅覚系一次中枢 である触角葉へと伸ばしている (図 1C). 空気中の匂 い分子は嗅感覚子のクチクラ上に吸着, 拡散し, 嗅孔を 
通り感覚子内部へと入る. 感覚子の内部は感覚子リン パ液で満たされているため, 揮発性で親油性の高い匂い 分子はそのままでは感覚子リンパ液を通過するのは難 しい，そのため昆虫は感覚子リンパ液中に小型で可溶 性の㫐い結合タンパク質 (odorant binding protein : OBP）を分泌して抢り，匂い分子は OBP と結合する ことで感覚子リンパ液中に可溶化, 濃縮され樹状突起 膜へと輸送される. OBP は昆虫ごとに数 10 種類あり 匂い分子に対する親和性が異なるものがあることから， 匂い分子の可溶化による高感度化に加えて, 感覚子内 に選択的に匂い分子を可溶化することで匂い受容の選 択性にも関与することが示唆されている。OBPによ り輸送された匂い分子が樹状突起膜上に発現する嗅覚 受容体 (odorant receptor) に結合すると匂い分子の 化学情報が受容神経の電気信号へと変換され，この情 報が軸索を通じて触角葉へと伝達され匂いが知覚され $ろ^{1)}$.

脊椎動物の嗅覚受容体が $\mathrm{G}$ タンパク質共役型受容体 ファミリーに属しており細胞内の代謝経路を介して匂 いを検出するのに対して, 昆虫の嗅覚受容体は共受容体 （Orco）とへテロ複合体を形成し匂い分子の結合によっ て開口する非選択的陽イオンチャネルとして機能する2) (図 1D). 嗅覚受容体遺伝子は昆虫種ごとに数種から約 300 種がゲノム上に存在しており,これらの嗅覚受容体 が上記の嗅覚受容体複合体の匂いへの応答特性を決定す る. キイロショウジョウ (Drosophila melanogaster ${ }^{3)}$ やハマダラカ (Anopheles gambiae $)^{4,5) を は し ゙ め, ~ い ~}$ くつかの昆虫種で嗅覚受容体の網羅的な応答解析が進 められ, 嗅覚受容体は少数の匂い物質だけに選択的に 応答するタイプから多様な匂い物質に幅広く応答する タイプまで，さまざまな選択性を示す嗅覚受容体が連 続的に分布することが示されている，また，種によっ て嗅覚受容体が受容する匂い物質の範囲に違いがあり, 例えばキイロショウジョウバエでは植物由来のエステ ルやアルコール類への応答性が高いのに対して ${ }^{3)}$, 八 マダラカでは人の汗に含まれる芳香族化合物やへテロ 環状化合物に対して応答性が高いことが報告されてい $ろ^{4,5)}$. この違いは, それぞれの種の生態学的ニッチに 起因すると考えられている。昆虫は地球上のさまざま な環境に適応しており，生息地によって有用な匂い情 報が異なることが推測される。そのため，今後多様な 環境に生息する昆虫種の嗅覚受容体の解析が実施され ることで，さまざまな匂い物質に対する嗅覚受容体が 単離同定され以下に述べるセンサ素子として利用され ることが期待される。

\section{3. 匂い源定位する「センサ昆虫」}

さまざまな応答特性を持つ嗅覚受容体を利用して, 特 定の匂いの発生源を高感度に探知するバイオセンサと して, ガ類昆虫の一種であるカイコガ (Bombyx mori) を利用したセンサ開発が進められている.カイコガの オスは, メスが放出する性フェロモンの匂い（(E,Z)10,12-hexadecadien-1-ol：ボンビコール）をきわめて 高感度かつ特異的に検出し, フェロモン源であるメスへ と定位する ${ }^{6)}$ 。この定位行動はオスの触角にあるボン ビコールの受容に特化した嗅覚受容神経 (以下, ボンビ コール受容神経）が活性化することで発現する。ボン ビコール受容神経の応答選択性はこの細胞で発現する $\mathrm{BmOR} 1$ と呼ばれるボンビコール特異的な嗅覚受容体 の機能による7 そ . そのため, ボンビコール受容神経に 検出対象の匂いに対する嗅覚受容体を導入し応答選択 性を改変することで, 対象の匂いを高感度に検出しそ の発信源に探知するカイコガを作出できる可能性があ る(図 2)、筆者らは, BmOR1 遺伝子の上流配列をプ ロモーター配列に用いた遺伝子組換えカイコガを作出 し, ボンビコール受容神経で特異的に外来遺伝子を発 現する技術を確立し, 農業害虫であるコナガ (Plutella xylostella) の性フェロモン（Z-11-hexadecenal）に特 異的な受容体 PxOR1 $1^{10)}$ をボンビコール受容神経で発 現するカイコガを作出した。 その結果, PxOR1 発現 カイコガのボンビコール受容神経は本来全く応答をし ない Z-11-hexadecenal に応答を示すようになり, 行動 レベルでも Z-11-hexadecenal 㧍よびメスのコナガに 定位することが示された ${ }^{11)}$.これにより, ボンビコー ル受容神経に他種の嗅覚受容体を導入することで, カ イコガを対象臭を検知して匂い源定位する「センサ昆 虫」として作出する基盤技術が確立したと言える. 本 技術を利用して現在，カビ臭成分を検知して定位する センサ昆虫の開発も達成されている。

\section{4. 匂いを蛍光変化としてとらえる「センサ細胞」}

昆虫の嗅覚受容体を含む多くの膜タンパク質は, 一 般的に, 異生物種に由来する培養細胞を活用して再構 築され，その機能が解析されている ${ }^{12)}$.これまでに， 大腸菌, 酵母, 哺乳類や昆虫由来の培養細胞を用いた タンパク質発現系, 細胞抽出液を利用した無細胞タン パク質発現系などの発現系技術が膜タンパク質の機能 解析に広く使用されている. 中でも昆虫の嗅覚受容体 は, Orco とともにイオンチャネルとして機能すること から, 主に匂い受容時のイオン電流を計測できる電気 生理学的手法やイオン濃度変化を計測できるカルシウ 

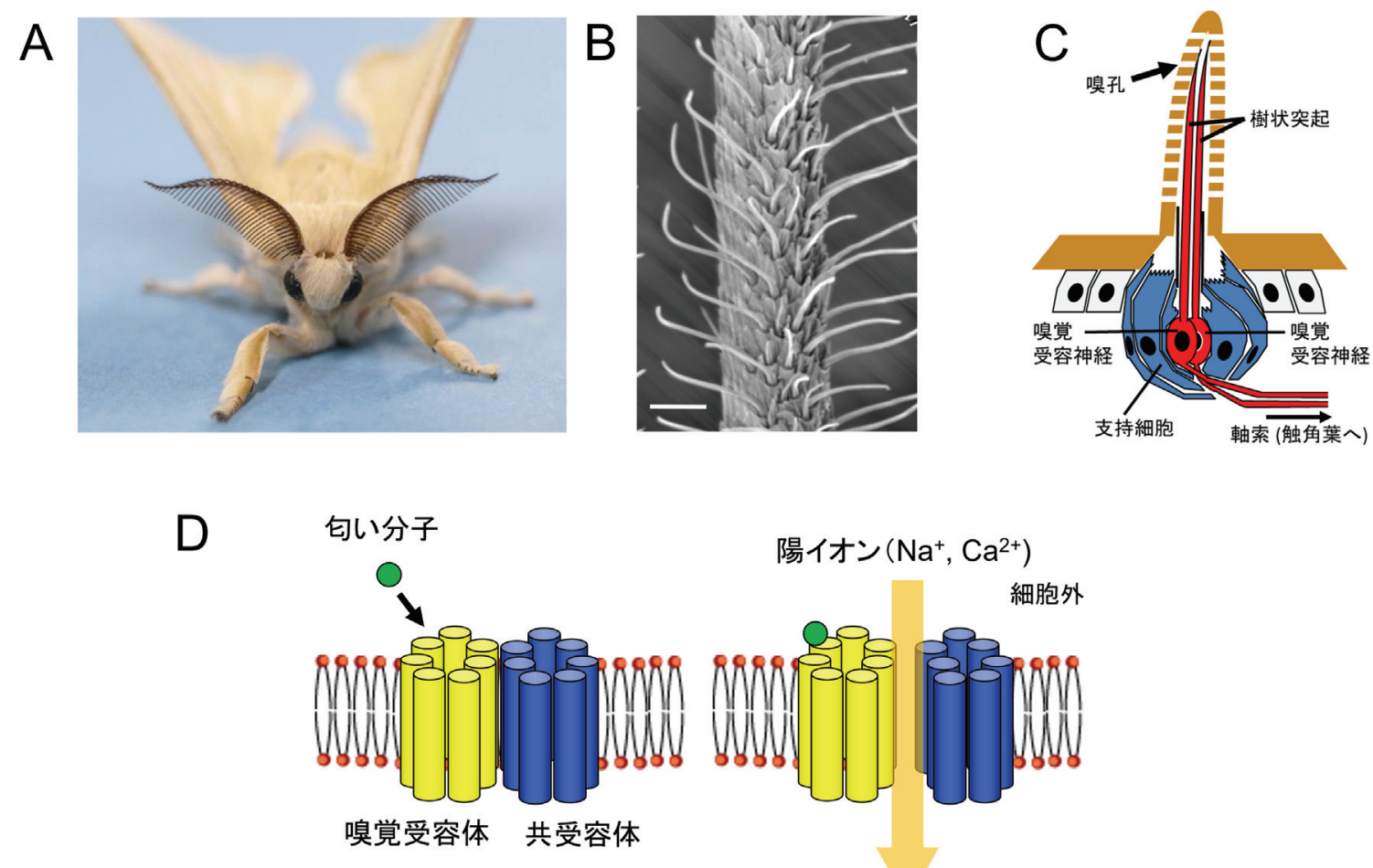

細胞内

\section{化学信号}

\section{電気信号}

\section{情報変換}

図 1 昆虫の触角と嗅覚器官の構造. (A) 昆虫（カイコガオス）の正面写真. 昆虫は頭部に付属する一対の触角 で匂いを検出する.（B）カイコガオス触角の走査型電子顕微鏡写真. 触角上の毛状の突起構造 (嗅感覚子) が匂いの受容器としてはたらく. スケールバー : $25 \mu \mathrm{m} \quad(\mathrm{C})$ 嗅感覚子の模式図. 感覚子の基部に嗅覚受容 神経の細胞体があり, 樹状突起を感覚子内部に軸索を触角葉へと伸ばしている。（D）昆虫の嗅覚受容体は 共受容体 Orco とへテロ複合体を形成し，匂い分子の結合によって開く陽イオンチャネルとしてはたらく.

ムイメージング法が可能な培養細胞，すなわちアフリ カツメガエル卵母細胞や HEK293T 細胞，Sf9 細胞な どが機能解析に使用されている13).

アフリカツメガエル卵母細胞は, アフリカツメガエル (Xenopus laevis) のメスから摘出された細胞であり, 発生段階のステージ V-VI でおよそ $1 \mathrm{~mm}$ となる巨大 な単細胞である。そのため，ガラスキャピラリを用い た核酸の微量注入 (e.g. マイクロインジェクション法) やガラス電極を用いた電極電気生理学的手法 (e.g. 2 電極膜電位固定法）が比較的容易に実施できる。これ までに，キイロショウジョウバエ (D. melanogaster) やハマダラカ (A.gambiae ) など, 多くの嗅覚受容体 の機能の同定が行われ，さまざまな匂い物質に対する
選択性が決定されている ${ }^{13)}$.

哺乳類由来の HEK293T 細胞や HeLa 細胞, 昆虫由 来の Sf9, Sf21 細胞, S2 細胞もまた, 昆虫嗅覚受容体 の機能再構築が可能である ${ }^{12)}$. 通常, リポフェクショ ン法やエレクトロポレーション法などの遺伝子導入手 法により, 対象遺伝子が細胞内へ導入される. パッチ クランプ法による電流計測やカルシウムイメージング 法による蛍光計測を用いて遺伝子導入した細胞の反応 を計測することで, 嗅覚受容体の応答が評価できる. このように, 昆虫の嗅覚受容体は, アフリカツメガエ ル卵母細胞や培養細胞で再構築でき，その反応は電流 值や蛍光変化值として読み取ることができる ${ }^{13,14)}$. そこで, 昆虫の嗅覚受容体の匂い応答を信号出力す 
野生型カイコガオス

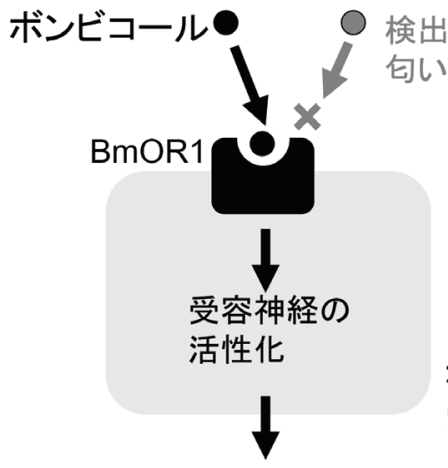

脳内のボンビコール情報 処理経路の活性化

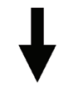

ボンビコール源への定位行動
嗅覚受容体導入カイコガ

（旬いセンサ昆虫）
ボンビコール

受容神経
嗅覚受容体導入に よる応答性の改変
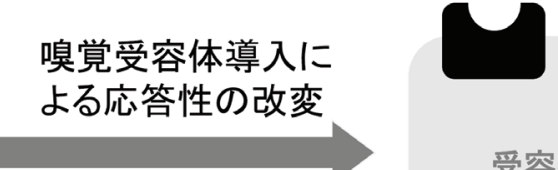

○ก対象の匂い物質に 反応する受容体

受容神経の

活性化

\section{$\downarrow$}

“検出対象の匂い物質”の刺激による敛内の ボンビコール情報処理経路の活性化

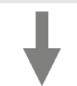

検出対象の匂い源への定位行動

図 2 「華昆虫」のコンセプト，野生型カイコガのオスでは，BmOR1 にボンビコールが結合することによ り，ボンビコール受容神経の神経興奮が引き起こされる。この情報が脳で処理されボンビコール源への定 位行動を解発する (左)，遺伝子組換えにより，ボンビコール受容神経に検出対象とする匂い物質に結合す る嗅覚受容体を導入すると，受容神経が検出対象の匂い物質に対して神経興奮を起こすようになる。これ により，検出対象の㫐い物質の発生源への定位行動が発現する (右).

る它い検出素子，すなわち「センサ細胞」を作出するた めに，筆者らは Sf21 細胞に着目した.Sf21 細胞は, ツ マジロクサヨトウ (Spodoptera frugiperda) の蛹卵巣 由来の培養細胞であり, リポフェクション法による遺 伝子導入, 大量発現, 遺伝子導入細胞の系統化など, 哺 乳類の培養細胞と同様に, タンパク質の機能発現に利 用できる. 加えて, Sf21 細胞は昆虫特有の性質も備え ており, 分裂回数に制限がない, 幅広い温度条件（18～ $\left.29^{\circ} \mathrm{C}\right)$ で培養できる, 二酸化炭素 $\left(\mathrm{CO}_{2}\right)$ の供給がいら ないなど, 哺乳類の培養細胞よりも培養の点で有利な 特徵をもつ．実環境下への適用を考慮して，この Sf21 細胞の特徵に着目して匂い検出素子の作出を試みた。

嗅覚受容体の応答特性に従って蛍光応答を示す細胞 ができれば，対象臭を検出する素子が作出できる。こ の考えのもと, 昆虫の嗅覚受容体とOrcoに加えて, 匂 い応答時に細胞内へ流入するカルシウムイオンを結合 する蛍光タンパク質 $\left(\mathrm{GCaMP}^{15,16)}\right)$ をすべて Sf21 細 胞に遺伝子導入することで，これら 3 種類の遺伝子を 機能発現する細胞, すなわち「センサ細胞」を樹立し た $(\text { 図 3 })^{17)}$ 。 センサ細胞の匂い応答のしくみは以下の 通りである。
(1)匂い物質が嗅覚受容体に結合すると, 嗅覚受容体 とOrco が構成するイオンチャネルが開く.

(2)カルシウムイオンが細胞内へ流入し, 細胞内の GCaMP6s と結合する.

(3) GCaMP6s の蛍光強度が増加して, センサ細胞自 体の蛍光強度が増加する。

(4)匂い物質がはがれると, 細胞内カルシウムイオン 濃度が減少し, センサ細胞自体の蛍光強度も減少 する。

この原理を検証するために，まずカイコガ (B. mori) の性フェロモン受容体, 共受容体 Orco, そして GCaMP を用いて細胞系統を作出し, この細胞が対象の性フェ ロモン成分に蛍光応答を示すことを明らかにすること で，匂いの検出素子となる「センサ細胞」作出の基盤 技術を確立してきた ${ }^{18)}$.

5. センサ細胞により蛍光パターンとして 匂い混合物を識別する「匂いセンサ技術」

昆虫の嗅覚受容体, Orco とともに GCaMPを遺伝 子導入した「センサ細胞」は, 受容体の応答特性に従っ て対象臭を検出する素子として活用することができる. 


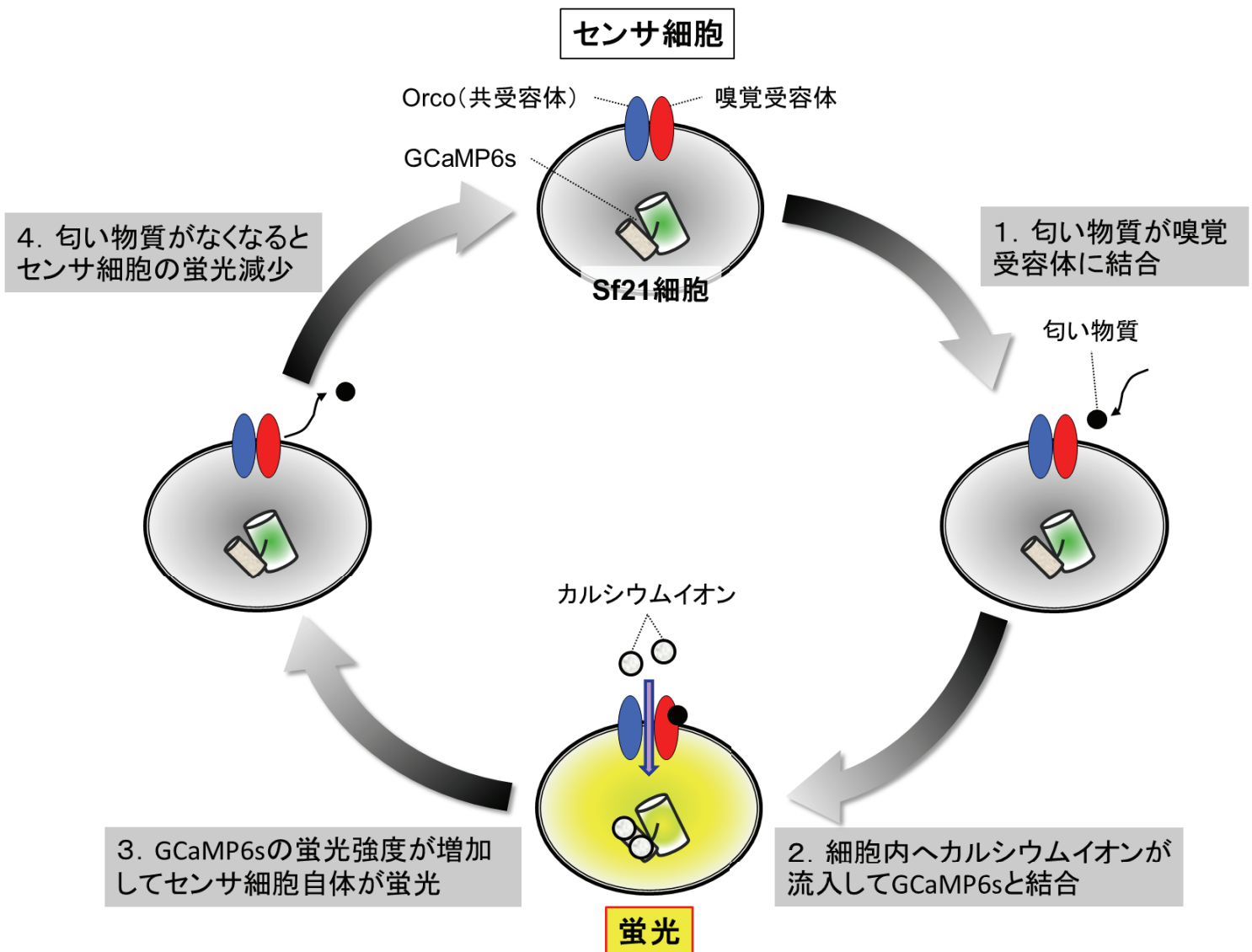

図 3 匂いに蛍光応答を示す「センサ細胞」のしくみ (文献 17) を改変).

原理検証で用いた性フェロモン受容体と同様に，一般 臭を検出する嗅覚受容体もOrco とともにイオンチャ ネルとして機能する2). そのため, さまざまな一般臭嗅 覚受容体に適用することで, 異なる対象臭を検出するセ ンサ細胞の作出が可能である。そこで，キイロショウ ジョウバエ (D. melanogaster) の嗅覚受容体を対象に して, 一般臭に対して蛍光応答を示すセンサ細胞の作出 を試みた。ここでは, キイロショウジョウバエの嗅覚受 容体である Or56a と Or13a を用いた. Or56a はカビ 臭成分の一つであるジェオスミン (Geosmin), Or13a はキノコ臭でありヒト体臭にも含まれる成分である 1オクテン-3-オール (1-Octen-3-ol) を選択的に受容す る。それぞれのセンサ細胞を作出した結果, Or $56 \mathrm{a}$ を導 入したセンサ細胞はジェオスミンに特異的に蛍光応答 を示す一方, Or13a を導入したセンサ細胞は 1-オクテ ン-3-オールに最も強く, 類似物質にも弱く蛍光応答を 示した。それぞれのセンサ細胞の匂い選択性は Or56a
と Or13a で報告されている匂い選択性 ${ }^{19,20)}$ とほぼ一 致し, 導入した嗅覚受容体に従って蛍光強度変化を示 すことが分かった。

次に, 生物の嗅覚と同様に, 嗅覚受容体の応答パター ンにより，匂いを識別できるかどうかを検証するため に, 異なる嗅覚受容体を発現させた複数種類のセンサ細 胞アレイを構築した ${ }^{21)}$ 。ここでは, 細胞膜修飾郕であ る PEG 脂質 ${ }^{22)}$ 用いて，それぞれカイコガの性フェ ロモン受容体である BmOR1, BmOR3, キイロショウ ジョウバエの一般臭嗅覚受容体である Or56a, Or13a を発現させた 4 種類のセンサ細胞のアレイを構築した (図 4A)。まず, 構築したセンサ細胞アレイを 4 種類の 対象成分 (ボンビコール, ボンビカール, ジェオスミン, 1-オクテン-3-オール）の混合物で刺激した結果, すべ ての区画のセンサ細胞が蛍光応答を示し, 複合物での 刺激であることが観察された。次に，単一成分で刺激 した結果, 1-オクテン-3-オール刺激時には Or13a セン 


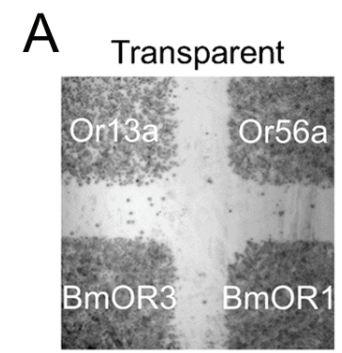

1-Octen-3-ol
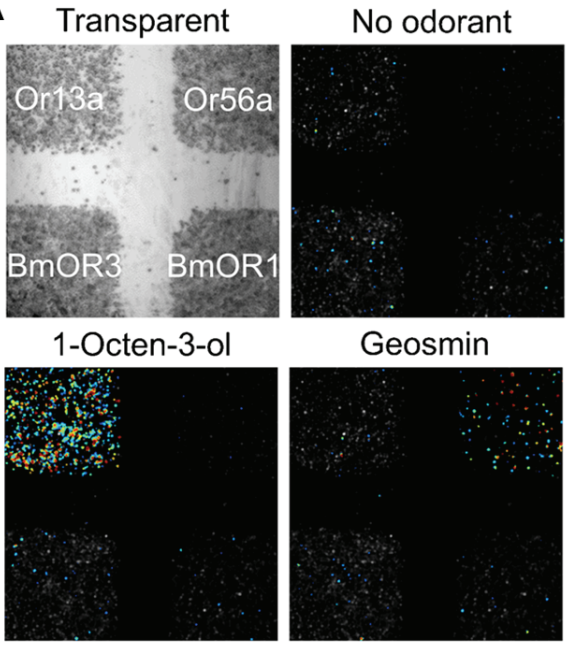

Bombykal

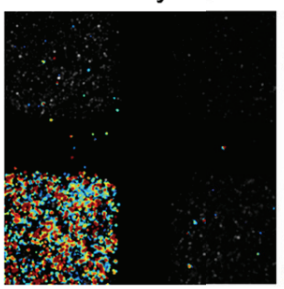

Bombykol

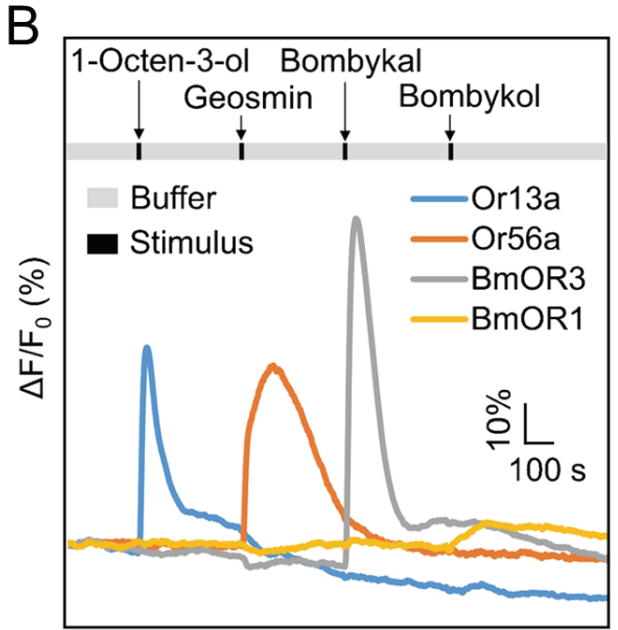

C

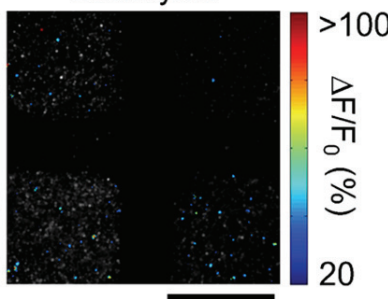

$500 \mu \mathrm{m}$

Time (s)

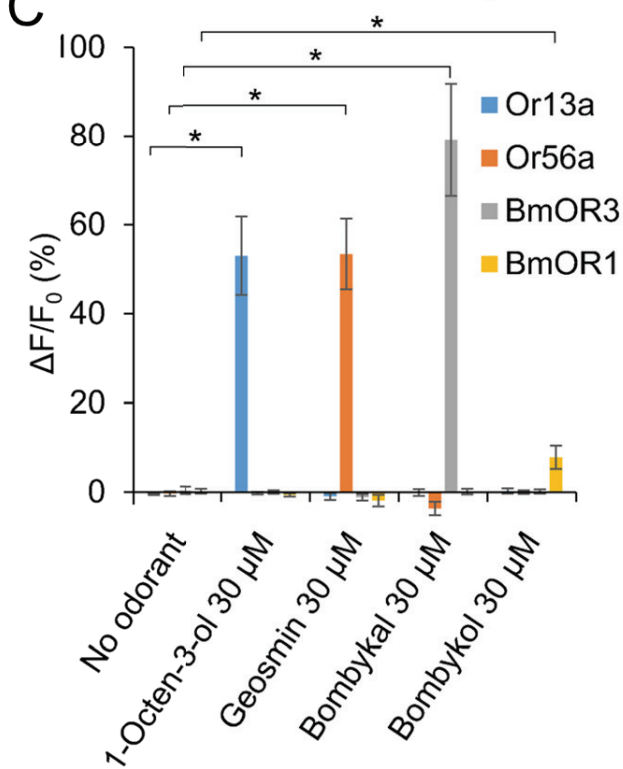

図 44 種類のセンサ細胞アレイによる匂いの識別 ${ }^{21)}$. ン.（B）センサ細胞アレイの蛍光強度変化率（ サ細胞の蛍光強度変化率.

サ細胞の区画のみ，ボンビカール刺激時には BmOR3 センサ細胞の区画のみといった法則に従い, 蛍光パター ンが観察された（図 4A）。この蛍光強度変化にもとづ き, 経時変化と蛍光強度変化率を計測した結果, セン サ細胞が応答しない非対象臭に対しては蛍光強度変化 を示さない一方，対象臭に対しては蛍光強度変化を示 すといった明確な応答パターンが取得できることが分
かった（図 4B，C). 以上の結果から，嗅覚受容体を 発現させたセンサ細胞をアレイ化することにより, 生 物の嗅覚と同様に, 蛍光パターンとして匂いの識別が 可能であることが明らかとなった ${ }^{21)}$. 


\section{6. センサ細胞により匂い混合物を濃度定量する 「匂いセンサ技術」}

昆虫は複数の受容体の応答を環境からの入力として, その応答パターンから匂いを認識し行動を出力してい ると言われている。しかし, 受容体での応答からさら に高次の情報処理がどのように実現されているかは, 未だ明らかにされていない。一方で，匂いセンサを入 力素子として情報処理を行い, その出力として機器の 制御や状態の評価を行うというような産業・実環境利 用の立場からは, 匂いの識別に加えて, それら匂い成分 の濃度を同定し, 混合物としての匂いの性質を明らか にしたいという需要も想定される。そこで, 計測工学 的な知見を活用することで, センサ細胞の応答パター ンから它い成分濃度を定量化する手法を提案した ${ }^{23)}$. 本章ではその原理検証実験の結果を簡単に紹介する。

計測工学における能動センシング法は, 測定対象に 応じて測定システム自身を動的に変化させる制御を行 うことで, システムが測定可能な範囲を拡張すること ができる計測手法である. 図 $5 \mathrm{~A}$ は，この計測手法を センサ細胞の蛍光応答パターンを用いた匂い成分濃度 の定量問題へと適用する場合のデー夕処理の流れを示 したものである。この手法では測定システムによって， 測定したい它いと同等な匂い成分から成る匂い混合物 を新たに作り出し，その計測值を利用することで包い 成分の濃度を決定する。具体的な手順を以下に示す. まず，測定システムはセンサ細胞を並べたセンサアレ イから, 匂いに対する応答を蛍光画像として取得する. このとき, 測定したい対象となる成分濃度が未知の匂 い(被測定臭) と，測定システムが調製した成分濃度 が既知である匂い（調製臭）の 2 つの匂いを測定する. 続いて, それら応答パターンを比較し, 両者の差分（誤 差）の情報を利用して，濃度探索アルゴリズムに基づ き調製臭の成分濃度を更新し, 新たな調製臭を作り出 して再び計測する。この匂い応答計測と応答パターン 比較，匂い成分濃度の更新を繰り返して被測定臭と調 製臭の応答パターンの差を小さくしていき，その誤差 が十分小さくなったとき，調製臭は被測定臭と同一で あるとみなすことができる。このような手順で匂い成 分濃度を決定する。この手法では, 被測定臭は調製臭 に含まれる成分の比として,つまり相対濃度が決定さ れることになる．仮に被測定臭を構成する真の匂い成 分が, 調製臭の成分として含まれない場合, 被測定臭 を近似するような調製臭が作り出されることになる.

ここでの濃度定量実験においては, Or56a を導入し たセンサ細胞と Or13a を導入したセンサ細胞の 2 種類
のセンサ細胞を利用してセンサアレイを構成した。 ま た, 匂いとして, ジェオスミンと1-オクテン-3-オール の 2 種類の成分を利用し, それぞれ 3 段階の離散的な 濃度レベル（0, low, high）だけが存在すると仮定し た.すなわち, 全部で 9 通りの組み合わせの混合物が 調製臭として調製可能な状態である (図 $5 \mathrm{~B}$ )。このう ち, 2 つの匂い濃度が high となる匂いを, 今回の被測 定臭として定義し実験を実施した。使用する濃度探索 アルゴリズムには, 滑降シンプレックス法を離散化お よび簡略化したアルゴリズムを採用した。このアルゴ リズムでは, 近接した 3 点の匂いを計測し, その誤差 值に基づいて 3 点が張る面（シンプレックス）を隣接 するシンプレックスへと移動させることを繰り返して, 誤差值の小さい場所を探索するものである。な拉，シ ンプレックスの遷移において, 先述の調製可能な濃度 域から逸脱しないような例外処理を設けた。また，七 ンサ細胞の応答のばらつきや時間的変動の影響を抑制 するために, 調製臭を測定するたびに被測定臭も改め て測定するという実時間参照方式 ${ }^{24)}$ を利用した.

図 $5 \mathrm{C}$ に上記濃度探索アルゴリズムを実行したとき の, 応答パターン誤差值の遷移結果を示す. 同図の通 り, シンプレックスを移動可能な範囲内で, 誤差が次 第に小さくなる方向にシステムが測定点を更新してい く動作が確認できる. 5 回目の更新においては測定点 の誤差が最小となって㧍り, 用意した被測定臭の成分 濃度と一致することがわかる. 以上の結果は, 2 つの センサ細胞を利用した最も簡単なセンサアレイによる 限定された濃度域, 濃度分解能での実験系を用いたも のであるが，センサ細胞の種類を増やすことや，調製 臭として利用する匂い成分を増やすこと，より洗練さ れた探索アルゴリズムを用いることで, さらに複雑な 匂いの濃度定量についても適用できるはずである。今 回は計測工学に基づく能動センシング法を利用するこ とで, 匂い成分の相対濃度定量を実現したが, 今後昆 虫をはじめとする生物における匂いの高次情報処理の しくみが明らかになれば，その情報処理の仕組みを活 用した匂い計測応用も展開できると期待している.

\section{7.おわりに}

本稿では, 昆虫の触角で機能する嗅覚受容体の機能 を再構築したセンサ技術について紹介した。 嗅覚受容 体の機能を培養細胞で再構築させることで受容体が備 える匂い選択性を再現でき, 異なる選択性のセンサ細 胞をアレイ化することで複数の匂い混合物を識別・濃 度定量できることを明らかにした。一方, 昆虫が備え る高性能な匂いの検出の再現には, 未だ到達できてい 
A
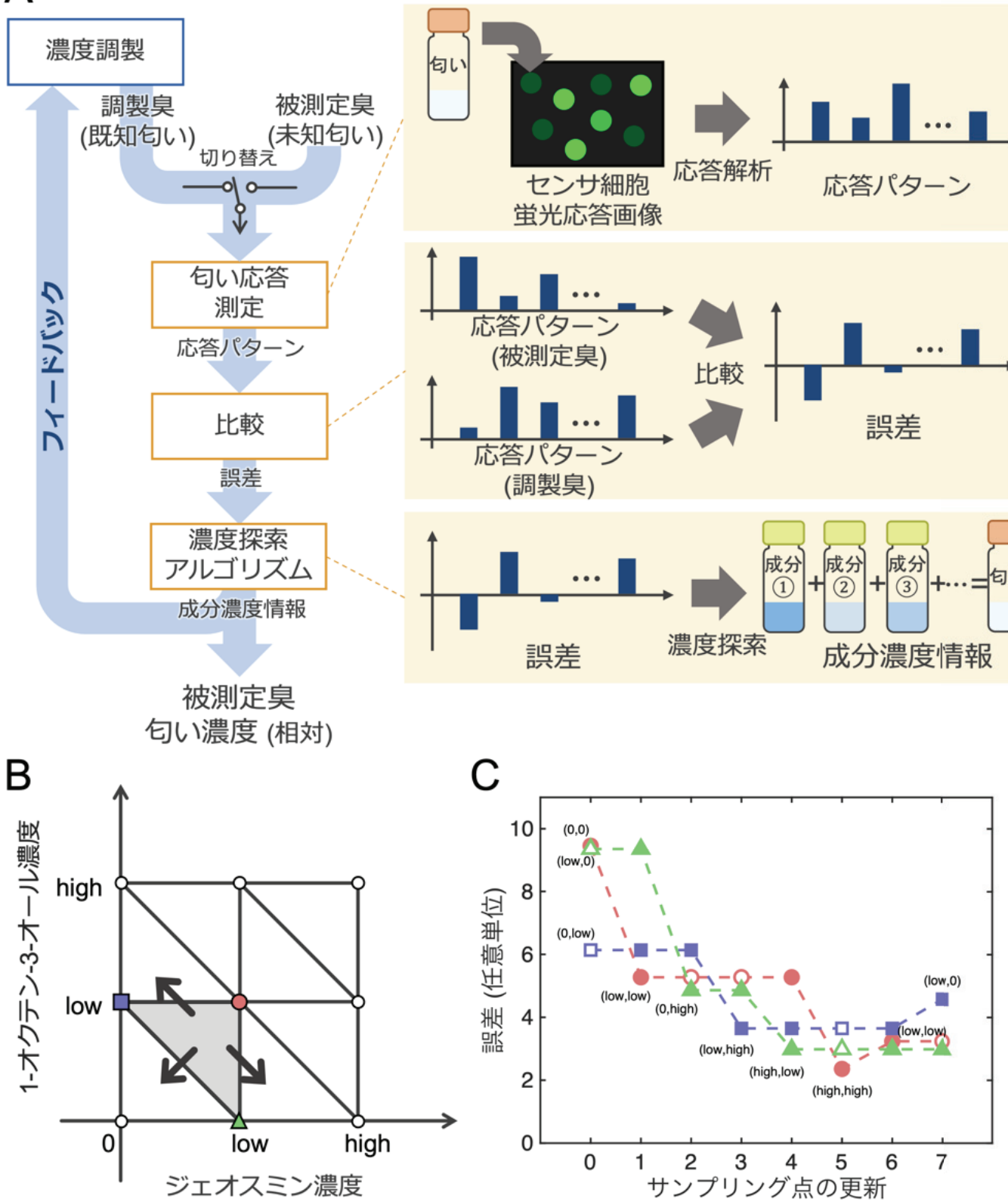

図 5 センサ細胞を用いた匂い成分の濃度定量 (文献 23) 改変)。(A) 能動センシング法を用いた匂い成分の濃 度定量の流れ。（B）原理検証における 2 成分の匂い濃度空間. 色付きの三角形は現在のシンプレックスの 位置であり，各頂点の誤差值に基づいてシンプレックスを移動させる (矢印方向). (C) 探索アルゴリズム による被測定臭と調製臭との応答パターン誤差についての状態遷移. 丸と三角形, 四角形の 3 つのデータ で 1 つのシンプレックスを構成する.デー夕点近傍にある括弧内はジェオスミンおよび1-オクテン-3-オー ルそれぞれの成分濃度を示す。 
ない，例えば，構造レベルでは，触角は匂い分子の捕捉 に効率的な構造や表面組成を備えていると考えられて いるが，そのしくみは未だ明らかにされておらず，利用 できていない状況にある。また，分子レべルでは，触 角内部には受容体に加えて匂い受容に関与する複数の 生体分子を備えているが，それらの生体分子を人工的 に再現した利用には至っていない，さらに，情報処理 レベルでは, 複数の受容体からの選択的な応答パター ンの入力は明らかになりつつあるが，高次中枢での情 報処理機構については未だ不明な点も多い。このよう に, 昆虫の嗅覚機能から学ぶしくみはまだまだ多く残 されている。これらのしくみを十分に理解し活用する ことができれば，昆虫のように環境の多様な匂い情報 を瞬時に捉え, 識別することができる真の嗅覚センサ の開発につながるものと期待される。

\section{参 考 文 献}

1) Sakurai, T., Namiki, S., Kanzaki, R. (2014): Molecular and neural mechanisms of sex pheromone reception and processing in the silkmoth Bombyx mori, Frontiers in Physiology, Vol.5, Article 125.

2) Sato, K., Pellegrino, M., Nakagawa, T., Nakagawa, T., Vosshall, L. B., Touhara, K. (2008): Insect olfactory receptors are heteromeric ligand-gated ion channels, Nature, Vol.452, pp.1002-1006.

3) Hallem, E. A., Carlson, J. R. (2006): Coding of odors by a receptor repertoire, Cell, Vol.125, pp.143-160.

4) Carey, A. F., Wang, G., Su, C. Y., Zwiebel, L. J., Carlson, J. R. (2010): Odorant reception in the malaria mosquito Anopheles gambiae, Nature, Vol.464, pp.66-71.

5) Wang, G., Carey, A. F., Carlson J. R., Zwiebel, L. J. (2010): Molecular basis of odor coding in the malaria vector mosquito Anopheles gambiae, Proceedings of the National Academy of Science of the United States of America, Vol.107, pp.4418-4423.

6) Butenandt, V. A., Bechmann, R., Stamm, D., Hecker, E. (1959): Über den Sexuallockstoff des Seidenspinners Bombyx mori. Reindarstellung und Konstitution, Zeitschrift für Naturforschung B, Vol.14b, pp.283-284.

7) Sakurai, T., Nakagawa, T., Mitsuno, H., Mori, H., Endo, Y., Tanoue, S., Yasukochi, Y., Touhara, K., Nishioka, T. (2004): Identification and functional characterization of a sex pheromone receptor in the silkmoth Bombyx mori, Proceedings of the National Academy of Science of the United States of America,
Vol.101, pp.16653-16658.

8) Nakagawa, T., Sakurai, T., Nishioka, T., Touhara, K. (2005): Insect sex-pheromone signals mediated by specific combinations of olfactory receptors, Science, Vol.307, pp.1638-1642.

9) Sakurai, T., Mitsuno, H., Mikami, A., Uchino, N., Tabuchi, M., Zhang, F., Sezutsu, H., Kanzaki, R. (2015): Targeted disruption of a single sex pheromone receptor gene completely abolishes in vivo pheromone response in the silkmoth, Scientific Reports, Vol.5, 11001 .

10) Mitsuno, H., Sakurai, T., Murai, M., Yasuda, T., Kugimiya, S., Ozawa, R., Toyohara, H., Takabayashi, J., Miyoshi, H., Nishioka, T. (2008): Identification of receptors of main sexpheromone components of three Lepidopteran species, European Journal of Neuroscience, Vol.28, pp.893-902.

11) Sakurai, T., Mitsuno, H., Haupt, S.S., Uchino, K., Yokohari, F., Nishioka, T., Kobayashi, I., Sezutsu, H., Tamura, T., Kanzaki, R. (2011): A single sex pheromone receptor determines chemical response specificity of sexual behavior in the silkmoth Bombyx mori, PLoS Genetics, Vol.7, e1002115.

12) Glatz, R., Bailey-Hill, K. (2011): Mimicking nature's noses: From receptor deorphaning to olfactory biosensing, Progress in Neurobiology, Vol.93, pp.270-296.

13) Mitsuno, H., Sakurai, T., Kanzaki, R. (2019): 4 - Sensing technology based on olfactory receptors, in Chemical, Gas, and Biosensors for Internet of Things and Related Applications, Elsevier, pp.39-64; doi: 10.1016/B978-0-12815409-0.00004-8.

14) Misawa, N., Mitsuno, H., Kanzaki, R., Takeuchi, S. (2010): Highly sensitive and selective odorant sensor using living cells expressing insect olfactory receptors, Proceedings of the National Academy of Sciences of the United States of America, Vol.107, pp.15340-15344.

15) Tian, L., Hires, S. A., Mao, T., Huber, D., Chiappe, M. E., Chalasani, S. H., Petreanu, L., Akerboom, J., McKinney, S. A., Schreiter, E. R., Bargmann, C. I., Jayaraman, V., Svoboda, K., Looger, L. L. (2009): Imaging neural activity in worms, flies and mice with improved GCaMP calcium indicators, Nature Methods, Vol.6, pp.875-881.

16) Chen, T. W., Wardill, T. J., Sun, Y., Pulver, S. R., Renninger, S. L., Baohan, A., Schreiter, E. R., Kerr, R. A., Orger, M. B., Jayaraman, 
V., Looger, L. L., Svoboda, K., Kim, D. S. (2013): Ultrasensitive fluorescent proteins for imaging neuronal activity, Nature, Vol.499, pp. 295-300.

17）光野秀文, 櫻井健志, 神崎亮平 (2020)：第 II 編 第 14 章 昆虫の嗅覚受容体を利用したセンサ細胞 およびセンサ昆虫, 匂いのセンシング技術, シー エムシー出版, 東京, pp.175-186.

18) Mitsuno, H., Sakurai, T., Namiki, S., Mitsuhashi, H., Kanzaki, R. (2015): Novel cell-based odorant sensor elements based on insect odorant receptors, Biosensors and Bioelectronics, Vol.65, pp.287-294.

19) Stensmyr, M. C., Dweck, H. K. M., Farhan, A., Ibba, I., Strutz, A., Mukunda, L., Linz, J., Grabe, V., Steck, K., Lavista-Llanos, S., Wicher, D., Sachse, S., Knaden, M., Becher, P. G., Seki, Y., Hansson, B. S. (2012): A conserved dedicated olfactory circuit for detecting harmful microbes in Drosophila, Cell, Vol.151, pp.1345-1357.

20) de Bruyne, M., Foster, K., Carlson, J. R. (2001): Odor coding in the Drosophila An- tenna, Neuron, Vol.30, pp.537-552.

21) Termtanasombat, M., Mitsuno, H., Misawa, N., Yamahira, S., Sakurai, T., Yamaguchi, S., Nagamune, T., Kanzaki, R. (2016): Cellbased odorant sensor array for odor discrimination based on insect odorant receptors, Journal of Chemical Ecology, Vol.42, pp.716724 .

22) Kato, K., Umezawa, K., Funeriu, D. P., Miyake, M., Miyake, J., Nagamune, T. (2003): Immobilized culture of nonadherent cells on an oleyl poly(ethylene glycol) ether-modified surface, Biotechniques, Vol.35, pp.1014-1021.

23) Sukekawa, Y., Mitsuno, H., Kanzaki, R., Nakamoto, T. (2021): Binary mixture quantification using cell-based odor biosensor system with active sensing, Biosensors and Bioelectronics, Vol.179, 113053.

24) Yamanaka, T., Nakamoto, T. (2003): Realtime reference method in odor recorder under environmental change, Sensors and Actuators B: Chemical, Vol.93, pp.51-56. 